\section{Diverging Routes}

Today, it is easy to ridicule the pursuits discussed throughout this book. They were already mocked in their own day. The French writer Pierre Loti and his fictitious mosque devoted to the mourning of an impossible intercultural love springs to mind. But the assumption made here is that they should be taken seriously because they say something about how one related to the past and inhabited the world in the age of empire, spectacle and industry. The past seemed proximate at the time, and the world wide open.

\section{Bygone Ways of Inhabiting the Past and} the World

Truly enough, most micro stories recounted in this book revolve around high culture and the upper end of society; they could be dismissed on the grounds of not representing the grass-roots of society. However, this would be missing an important part of the story, which is the popular appeal of the practices and experiences considered. Crowds dressing à la turque in time of carnival since the eighteenth century are a good example. Historian Edhem Eldem has shown that Orientalism was indeed a mass culture, and one that went global in no time at all. ${ }^{1}$

An influential American art critic, commenting in the 188 os on the broader pattern of aesthetic interiors and the passion for exotic historicism caustically deemed the endeavour as "insipid pedantry" and not the proper way to achieve "the independent creation of new and inventive belongings:"

1 Edhem Eldem, Un Orient de consommation (Istanbul: Musée de la Banque ottomane, 2010). See also Wolf-Dieter Lemke, Représentations de l'Orient.
The tendency of the day is not merely to classify buildings into the Grecian, the Egyptian, the Gothic and the like, but to prolong these just distinctions into our table-service and bedrooms, so that a salt-spoon may be of the Jacobean order, and may be reasonably commanded of an architect, and a night-cup may be of the chastest Louis Quinze. No growth in true taste ever came of an insipid pedantry like this. $^{2}$

The visitors drawn to the Parisian Musée de Cluny in those very years, as seen in Chapter 4, would be otherwise opinionated; they readily enjoyed the experience of immersive displays, as many commentators did, even if the past arranged for commercial consumption in the rooms of the medieval abbey was no less artificial and nostalgic than the one revived in collectors' interiors. It may have been an Old World phenomenon only, but enthusiasm for historicist multi-dimensional arrangements represented a rising tide in Europe. Through antique shops and department stores' showrooms, the culture of aesthetic historicism, and its paraphernalia, swiftly invaded European middle-class homes, establishing itself as a prime way of dwelling for many decades. ${ }^{3}$ A Louis XV hall or a Henry II dinner-room was not intrinsically different from an Oriental den or a Saracenic smoking room. As in David Lowenthal's paraphrasing of the opening of The Go-Between (1953), "the past is a foreign country." ${ }^{4}$ The phrase holds extraresonance today.

2 Edward Strahan [Earl Shinn], Mr. Vanderbilt's House and Collection (Boston: George Barrie, 1883-84), I: VII.

3 Charpy, Le Théâtre des objets, ch. 5 passim.

4 David Lowenthal, The Past is a Foreign Country (Cambridge, UK: Cambridge University Press, 1985), after Leslie P. Hartley's incipit of The Go-Between (1953). My

(C) MERCEDES VOLAIT, 2021 | DOI:10.1163/9789004449886_008

This is an open access chapter distributed under the terms of the CC BY-NC-ND 4.o license. 


\section{Estrangements}

The anonymous art critic who reviewed Vernet's Voyage dans le désert, after its presentation at the Paris Salon des artistes français in March 1844, ${ }^{5}$ had no trouble identifying the topic of the canvas, and the characters pictured:

Le Voyage dans le désert nous montre une caravane conduite par un Arabe. [...] L'Arabe qui conduit est fort beau; le principal voyageur, qui ressemble fort à Horace Vernet, est bien digne d'aller de pair avec l'Arabe. Si j'en crois ses armes, son chibouk, son regard intelligent, sa poétique insouciance, c'est bien là Horace Vernet. ${ }^{6}$

Whatever his disguise, Vernet was perfectly recognisable. It was not the case anymore a few decades later. The small piece had been acquired from the artist by the Marquess of Hertford in May 1844 for 4,00o francs. It had been registered in Hertford's ledgers under its original title. ${ }^{7}$ Yet it was not long before the painting acquired another identity. The circumstance was the public opening of the Hertford collection in London, from June 1872 to April 1875. After the death of the Marquess in 1870, his son Richard Wallace had repatriated the

gratitude to the anonymous reviewer who pointed out the literary origin of the phrase.

5 The canvas was no. 1757 in the catalogue of the Salon, Explication des ouvrages de peinture, sculpture, architecture, gravure, et lithographie des artistes vivants exposés au Grand Palais des Champs-Élysées (Paris: Vinchon, 1844), 219.

6 Anonyme, "Le salon, V," L'Artiste v (1844): 177-78 (178 for the quote). "Voyage dans le désert depicts a caravan guided by an Arab [...]. The Arab conductor is truly handsome; the main traveller, who deeply resembles Horace Vernet, forms a dignified pair with the Arab. If I believe his weapons, chibouk, acute gaze, and poetic insouciance, this is for sure Horace Vernet."

7 "The Livre de Raison gives: "1844, mai 1-27, un petit tableau Voyage dans le désert, 4,0oo f," Stephen Duffy \& Jo Hedley, The Wallace Collection's Pictures: A Complete Catalogue (London: The Trustees of the Wallace Collection, 2004), 449. artworks that were then housed in Paris, and a temporary loan had been arranged in the new annex that the South Kensington Museum had opened at Bethnal Green in London's East End. The collection was meant to relocate to Hertford House once the family mansion had been refurbished anew. The 2,000 artworks, among which were 700 paintings, were provided with proper cataloguing. A preliminary guide mentioned the painting as an Eastern scene devoted to "a group of Arab chiefs of the present day;" it was subsequently listed as Arab travelling [sic] under no. 591 in the complete catalogue released in $1872-74 .{ }^{9}$ Vernet's rendering of a memorable desert excursion had lost in the process its original title, and together with it, its very meaning. Three decades had sufficed to estrange the artwork from its true topic.

The renaming was probably the doing of the author of the catalogue, Charles Christopher Black, a specialist of Italian Renaissance who was then serving as curator in the South Kensington Museum. Was the singular given to the noun a typo or a misperception of the canvas? Did it translate a focus on the caravan's guide - an Arab indeed - or a misrepresentation of the travellers who were not Arab? In any case, an alteration had occurred. Another followed a few decades later, when the painting was again renamed. It became Arabs Travelling in the Desert, once the Wallace collection was permanently opened to the public, following the transformation of Hertford House into a museum after the death of RichardWallace. ${ }^{10}$ By 1905, the camel riders had been fully Arabised,

8 Charles Christopher Black, A Guide to the Bethnal Green branch of the SKM (London: Spottiswoode, 1872), 24.

9 Charles Christopher Black, Bethnal Green Branch Museum. Catalogue of the Collection of Paintings, Porcelain, Bronzes, Decorative Furniture, and Other Works of Art, Lent For Exhibition in the Bethnal Green Branch of the South Kensington Museum, by Sir Richard Wallace, Bart., M.P. June 1872 (London: George E. Eyre And William Spottiswoode, 1872-74), 39 .

10 It became no. 584 in the collection: Catalogue of the Oil Paintings and Water Colours in the Wallace Collection, with Short Notices of the Painters. By authority of the 
either because it made the artwork more appealing or because the very existence of Europeans wandering through the desert in the Middle East could not be conceived anymore. If one looks for exoticisation going on in the visual arts related to the region, the chronology and agency are clear cut in this case. The early 1870 set a first milestone; another followed three decades later. It was long after the piece had been painted and it was a matter of reception rather than artistry. An artwork from the not so distant past had become or was made incomprehensible to its later beholders. A connection to the experience of the Middle East, of the Egyptian desert for that matter, had been lost.

Vernet's Voyage dans le désert was not the sole canvas that was exoticised and ethnicised, through rebranding, after entering a public collection. Many others experienced similar fate. As Helena Heikka honestly acknowledged in her thorough and perceptive analysis of Berndtson's meaningful depiction of pastimes at the house of Delort de Gléon in Cairo (discussed in Chapter 5), no art historian or curator knowing the region primarily through popular culture, i.e. The Arabian Nights, would imagine that the astute canvas could be anything but an "a-historical fantasy."11 In this case again, the rebranding undoubtedly helped to distort the perception of the scene pictured. The small oil painting was listed as Intérieur de salon arabe au Caire when in the possession of its first owners, Delort de Gléon and his wife Angelina Grandcolas. At least it appeared under that name when the piece was bequeathed to Helsinki's Fine Arts Museum in a will of Mrs Delort dated $1905 .{ }^{12}$ It eventually reached the Ateneum Art Museum in Finland, and was renamed Almée, an Egyptian Dancer, at one point in the social life of the

Trustees of the Wallace Collection (London: HMso, 1905), 16o.

11 Heikka, "Layers of fantasy," 1.

12 Pierrefitte-sur-Seine, Archives nationales, Archives des musées nationaux, Mobilier et objets d'art, Dons et legs, Legs de Mme Delort de Gléon, 9 March 1914, $20144787 / 17$ (the canvas is mentioned in an early will dated 1st July 1905). painting. It is not known when, but it was in any case long after the canvas had been produced.

Misreading artworks when they have gone out of context actually represents a phenomenon of much broader scope. Another telling story engages a drawing by Prosper Marilhat, dated 12 May 1832, representing a man in Nizami guise smoking a water pipe while reclining on a bed. The location written on the drawing, "Kanka," offers some clue on its topic. The name stands for Khanqa, a site north-east of Cairo, where the French Doctor Clot-Bey had established a brand new military hospital in 1826: in times of epidemic or in case of serious illness, it accepted civilian patients. ${ }^{13}$ Possibly a self-portrait or a depiction of a recovering traveller, Marilhat's drawing was exhibited as Fumeur de narghileh in 1973, and as Égyptien fumant un narghilé two years later. ${ }^{14}$ The ethnic demarcation of the sitter occurs here at a much later stage than for Voyage dans le désert; it can be dated with even more precision, to a span of two years in the mid-1970s. The timing is not accidental. It was in the wake of decolonisation, a period defined by estrangement with colonial history, ${ }^{15}$ and willingness to acknowledge ethnic and national identities in visual representations from the colonial era, to the risk of stereotypical assignations, and possible misinterpretation, as happened with Voyage dans le désert and Fumeur de narghileh. I believe that many other artworks, too hastily classified as belonging to the Orientalist genre, need to be reread in this new light. Another eloquent example is Émile Prisse d'Avennes's Marché des esclaves (1848), which is not in fact a typical depiction of the purchase of an enslaved woman in Cairo, but a

13 Bruno Argémi, "Jomard, Clot Bey et la modernisation de la médecine dans l'Égypte de Méhémet-Ali," Bulletin de la Sabix 54 (2014): 23-30.

14 Prosper Marilhat (1811-1847), Peintures, dessins, gravures, exhibition catalogue (Clermont-Ferrand: Musée Bargoin, 1973), 19, no. 38; L'Orient en question, 1825-1875: de Missolonghi à Suez ou l'Orientalisme de Delacroix à Flaubert (Marseilles: Musée Cantini, 1975), 6o (reproduced 109).

15 Daniel Rivet, "Le fait colonial et nous. Histoire d'un éloignement," Vingtième siècle, revue d'histoire 33, no. 1 (1992): 127-38. 


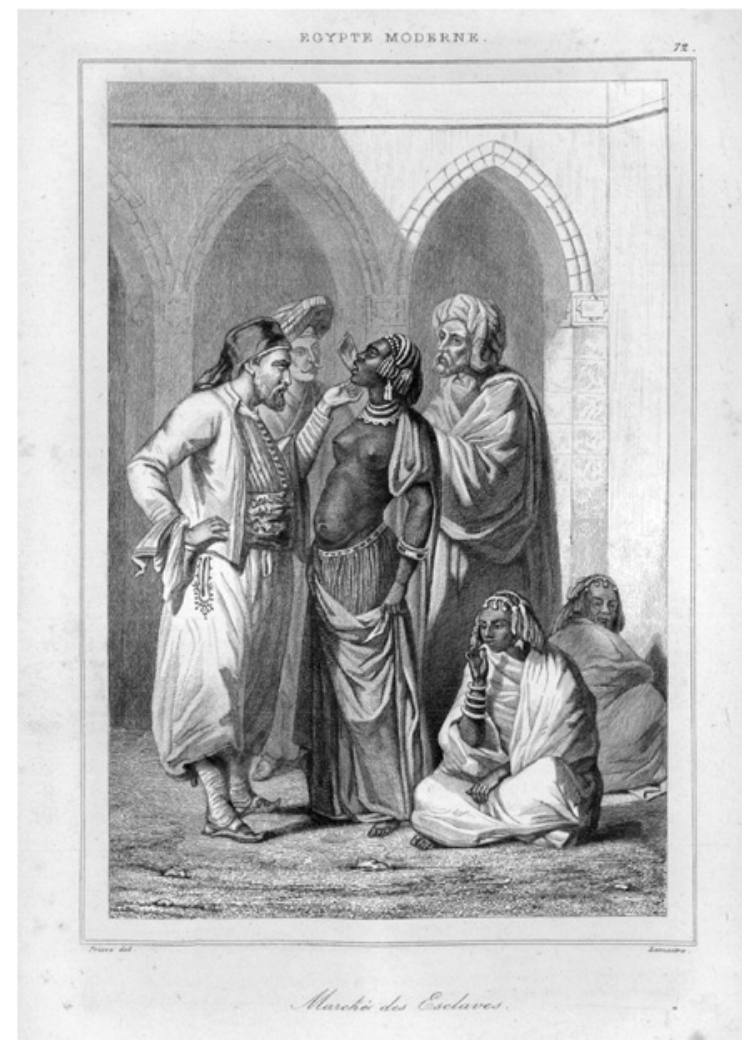

FIGURE 177
Émile Prisse d'Avennes, Marché des esclaves [The slave market]. Engraving JEAN-JOSEPH MARCEL AND AMÉDÉE RYME, HISTOIRE DE L'ÉGYPTE, L'UNIVERS OU HISTOIRE ET DESCRIPTION DE TOUS LES PEUPLES, DE LEURS RELIGIONS, MOEURS, COUTUMES.... 1848, III: PL. 72 caricature of John Frederick Lewis embarking into buying one. ${ }^{16}$ (Fig 177 and 178 )

For the past couple of decades, the harm of cultural appropriation, primarily understood as dispossession when involving the non-West, ${ }^{17}$ have made one wary of cross-cultural dressing and, for that matter, cross-cultural decorating. The sight of "ethnic" guise, when donned by outsiders, is one we have become increasingly uncomfortable with. We perceive even the most innocent fancy dressing as grotesque, at best. It would never occur to

16 Llewelyn, "Friend and Foe."

17 Deborah Root, Cannibal Culture: Art, Appropriation, and the Commodification of Difference (Boulder: Westview Press, 1996).

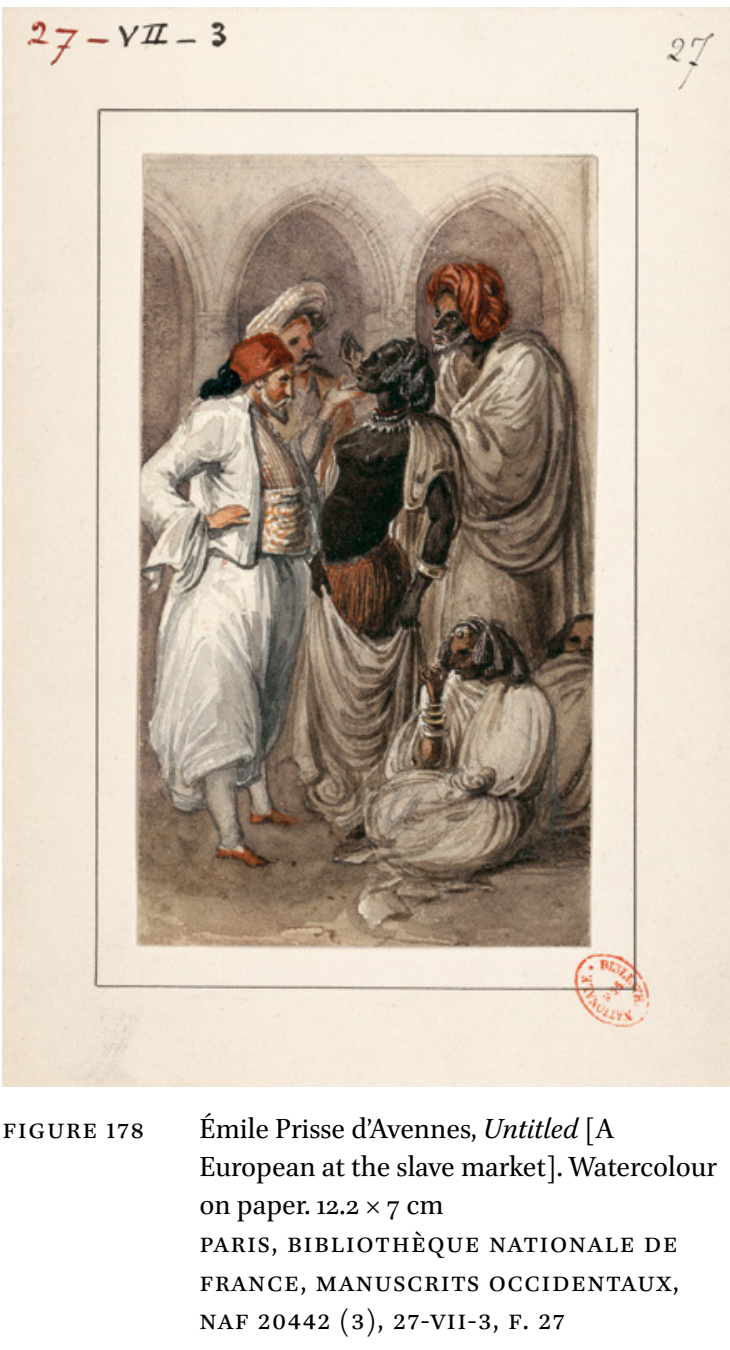

French scholars and artists in residence in academic institutions to dress cross-culturally, as was the tradition at the French Villa Medici in Rome since the eighteenth century, as seen in Chapter 5 , and as continued to be common practice at the French Institute for Archaeology and Islamic arts in Damascus during the 1920s, under the directorship of Islamic art historian and collector Victor Eustache (1875-1953), known as Eustache de Lorey. ${ }^{18}$ (Fig. 179)

Too many disturbing phenomena have been associated with masquerade in the past two

18 Renaud Avez, L'Institut français de Damas au Palais Azem (1922-1946) à travers les archives (Damascus: Presses de l'Ifpo, 1993), chapter 1 passim. 


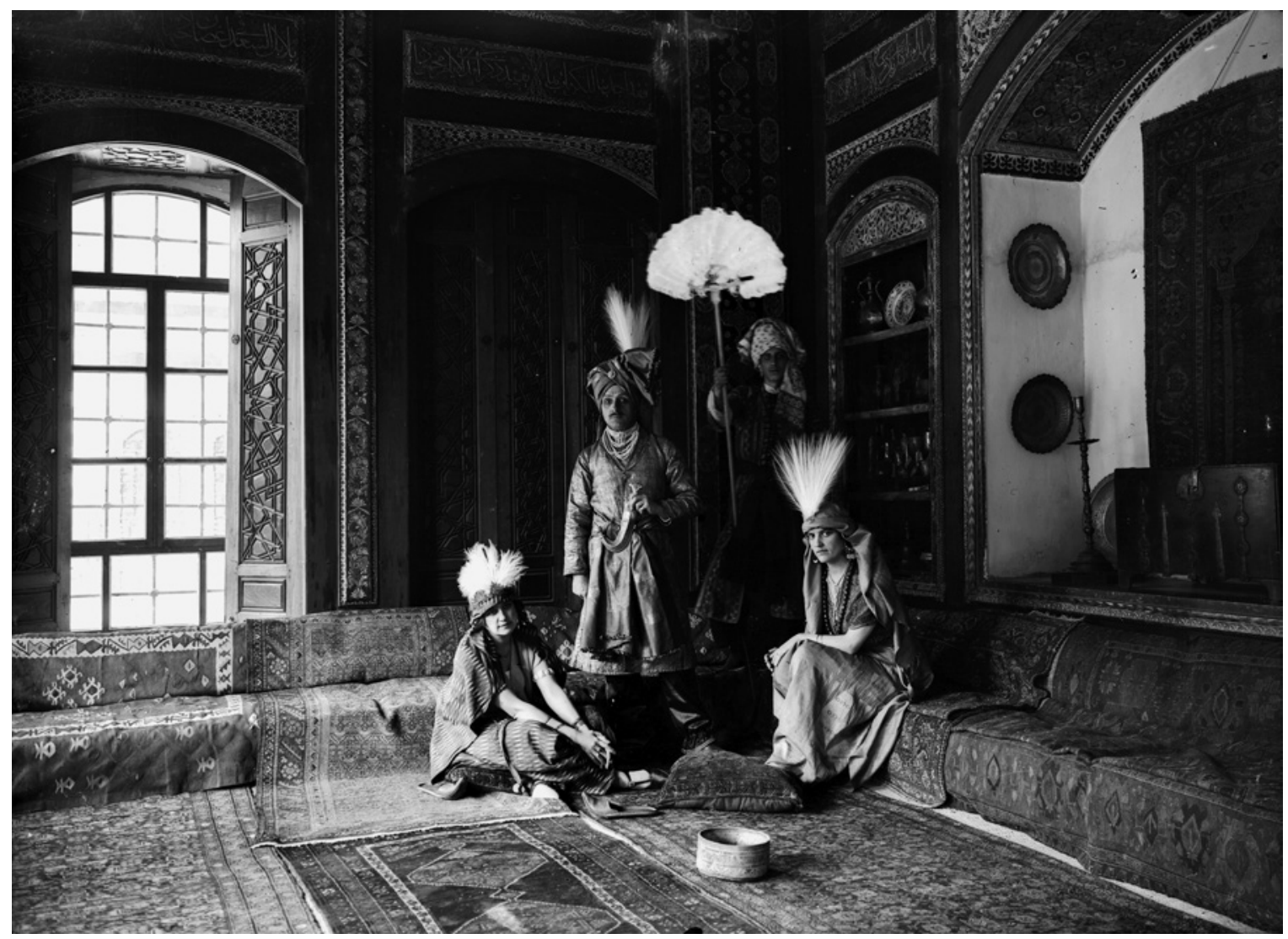

FIGURE 179 Anonymous, Untitled [Victor Eustache standing in Indian attire at a reception in the Azem Palace in Damascus], c. 1923. No dimensions provided BEIRUT, INSTITUT FRANÇAIS DU PROCHE-ORIENT, PHOTOTHÈQUE, 54769

centuries. One only needs to consider the ethnological parading of non-Western human beings at national exhibitions and world's fairs, for which the all-embracing concept of "human zoos" has been coined. ${ }^{19}$ Criticism has been addressed at its shortcomings and anachronistic amalgamations, ${ }^{20}$ but the powerful paradigm has fundamentally changed the way we look today at ethnic-oriented sartorial displays, whether they involve people of colour or not, and before even speaking of considering crossovers. Any initiative engaging

19 Nicolas Bancel et al., Zoos humains, de la Vénus hottentote aux reality shows (Paris: La Découverte, 2002).

20 Claude Blanckaert, "Spectacles ethniques et culture de masse au temps des colonies," Revue d'Histoire des Sciences Humaines 7, no. 2 (2002): 223-32. with ethnic identity crossing through clothing (or make-up) seems out of place, to say the least. Cross-dressing has become the realm and privilege of gender fluidity, not cultural trespassing. Little space is thus left to the ambivalent, entangled, and at times conflicted, cross-cultural history recounted in this book. Lost in the transition, however, are the personal engagements and social interactions that went with wearing, or attempting to wear, the other's garb. The same applies to reconstructing the other's space. It is significant, as pointed out by François Pouillon, that cross-cultural dressing has now strictly recessed to the private sphere. ${ }^{21}$ Ample clothing such as sarwal or jallabiyya is worn for comfort in the secrecy of interiors; its capacity

21 Pouillon, “Le fil d'Ariane," 143. 
to foster intercultural connections and mediations has become extinct.

\section{$3 \quad$ Endurances}

When shifting the focus to the other side of the Mediterranean, quite a different panorama emerges today. Rather than estrangement from the recent past what can be paradoxically noticed is its endurance. Many of the practices and experiences examined throughout the book are still alive in present-day Egypt. The commodification of salvage from derelict architecture is an index. A recent case is provided by an architect-designed house in Fayyum, completed in 2015. (Fig. 18o and 181) It features a portal from the late Ottoman Mosque of Fatima al-Nabawiyya in Cairo. When the sanctuary was demolished in $1999^{22}$ to give way to a new Mamluk Revival mosque (inaugurated in 2003), its stonework was properly dismantled by specialised workers and resold by the Ministry of Endowments. The sale followed a legal procedure. Recycling salvage was not illicit in the past, at least in most cases, and it is not in the present either. The house was designed by Omar El-Farouk, a follower of the celebrated Egyptian architect Hassan Fathy (1900-89) who searched for low-tech architectural solutions in Egypt's tangible heritage. ${ }^{23}$ El-Farouk is a collector with a passion for Islamic art and architecture. ${ }^{24}$ Combining salvage with Revival handicraft, his "dream house" corresponds to the pattern, explored in Chapter 4 , of a specific collecting culture that strived to shape total Revival environments in order to reclaim the past. There are differences too, however. The stonework and furniture of his Fayyum house possess an

22 My gratitude to Péter Nagy for providing the exact date of demolition.

23 James Steele, "The new Traditionalists," Mimar 40 (1991): 40-7; Abdullah Schleifer, "Islamic architecture and the discipline of design: the work of Omar El-Farouk," Arts of the Islamic World 2 (1984): 43-5, 49.

24 Menha El-Batraoui, "Un rêve d'architecte: Omar El-Farouk," Qantara 96 (July 2015): 57-6o. unmistakable South-East Asian touch, probably resulting from their overseas manufacture. The novelty here is not the salvage, nor the Revivalism, but the craftsmanship resorted to for its execution. Yet the link to architectural projects developed in the 1870 s, after the Cluny model, cannot be missed. The genealogy is indirectly acknowledged today by members of the recycling profession in Cairo who have chosen the French word "démolisseur" to name their trade.

On 25 December 1971, the New York Times reported that the charred ruins of Cairo's Opera house were to be sold to a demolition contractor for the extravagant amount of $\$ 48,100 .{ }^{25}$ The architectural emblem of the Khedivial contribution to the city's modern expansion had been destroyed by fire in October that same year. Its stones, plasterwork and mirrors went on to start a new life cycle. Since then, what is being commodified, to this day, are the remnants of the tangible culture that made Cairo modern. Leading the market are the very spoils of the Islamic Revival architecture at the core of Chapter 4. An example is the salvaging in 1995 of the marble mosaics designed by Ambroise Baudry for the Villa Delort de Gléon in 1871. Another is the looting in 2011 of Villa Ispenian by the Pyramids, a house built in 193536 by antique dealers Kevork and his son Paul Ispenian, where they had reinstalled part of the historic ceilings and Revival woodwork from Villa Baudry (after the architect's house had itself been dismantled), together with many other salvaged fragments. ${ }^{26}$ The recycling culture, or upcycling business to use the current parlance of the fashion

\footnotetext{
25 "Cairo Opera Ruins Sold," The New York Times, Sunday 26 December 1971, 42.

26 On the construction of Ispenian House, see Volait, Fous du Caire; for its looting during the Arab Spring, Omar El Adl, "Systematic ruin of Egypt's antiquities in Haram," Daily News Egypt, 3 January 2013; [https:// cairobserver.com/post/42575456931/destruction-alertvilla-ispenian], accessed 25 May 2020.
} 


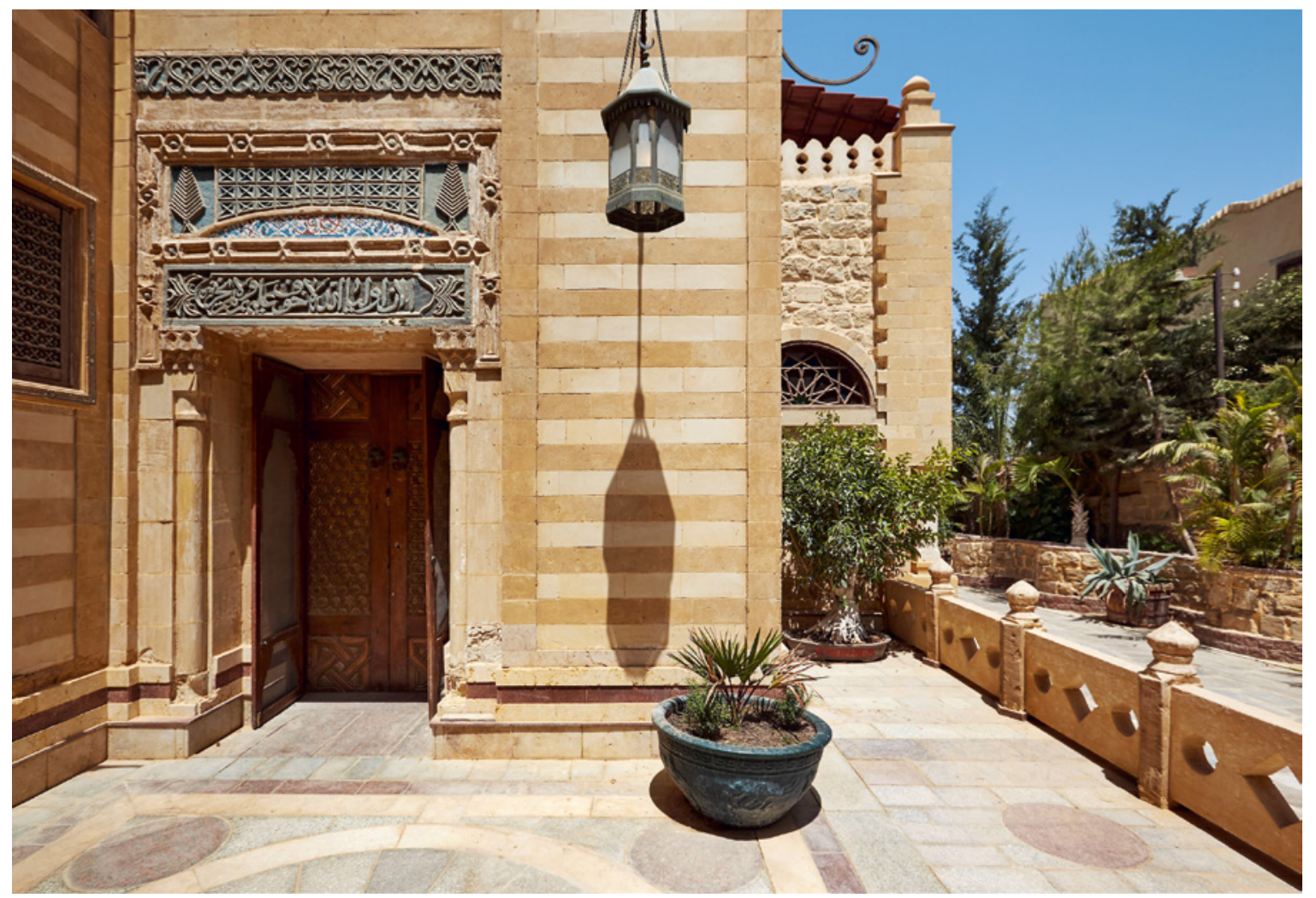

FIGURE 180 Entrance to a house designed by Omar El-Farouk in Fayyum with architectural salvage from the Mosque of Fatima al-Nabawiyya in Cairo

PHOTOGRAPH BY HAYSHAM LABIB, 2015

industry, continues to be in full swing. And it does not stop at Islamic Revival architecture. ${ }^{27}$

The Islamic Revival crafts of the late nineteenth and early twentieth century fare no less well on the art market, at international level in their case. A pair of Revival glass lamps made in 1911 for the family mansion that civil engineer and financier Boghos Nubar (1851-1930) had built in the suburb of Heliopolis in Cairo, were sold for $£_{17,500}$ when they were recently auctioned in London. ${ }^{28}$

27 I have discussed elsewhere the reappraisal of all kinds of "Belle époque" architecture; Mercedes Volait, "The reclaiming of 'Belle Époque' Architecture in Egypt (19892010): On the Power of Rhetorics in Heritage-Making," Architecture beyond Europe 3 (2013) [https://journals .openedition.org/abe/371], accessed 25 May 2020.

28 "A pair of enamelled glass mosque lamps made for the house of Boghos Nubar," Arts of the Islamic World,
(Fig. 182) Furniture by Giuseppe Parvis regularly appears in auction rooms too; recognisable pieces from his workshop are becoming collectibles in the Gulf, for instance in Qatar. ${ }^{29}$ (Fig. 183 and 184)

But the reappraisal of Islamic Revival crafts should not be considered a global one only; many signs suggest that the phenomenon thrives in Egypt too. It is particularly active in the field of museums.

Sotheby's London, 25 October 2017, lot 231. The house was sequestrated after 1952, but as was usual and legal, portable furniture and fixtures remained the property of the original owner, in this case the descendants of Boghos Nubar who lived in France since the 1920s and transferred back the spoils of their Cairene residence.

29 Mercedes Volait, "Revival, replica and reuse: Fashioning 'Arabesque' furniture in Khedival Cairo," The Arabist, Budapest Studies in Arabic 41 (2020): 229-42. 


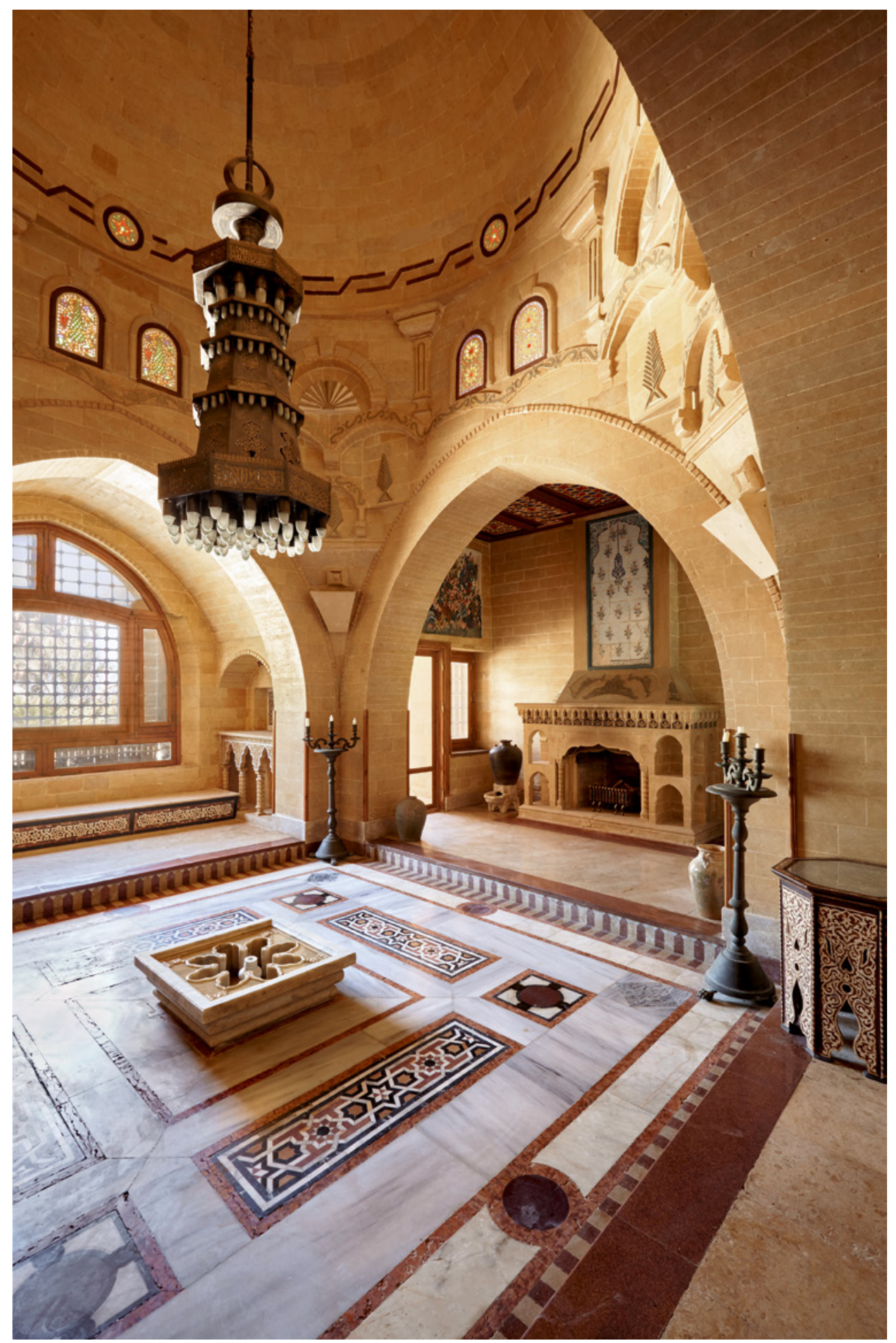

FIGURE 181

Interior of a house in Fayyum, designed by Omar El-Farouk PHOTOGRAPH BY HAYSHAM LABIB, 2015 


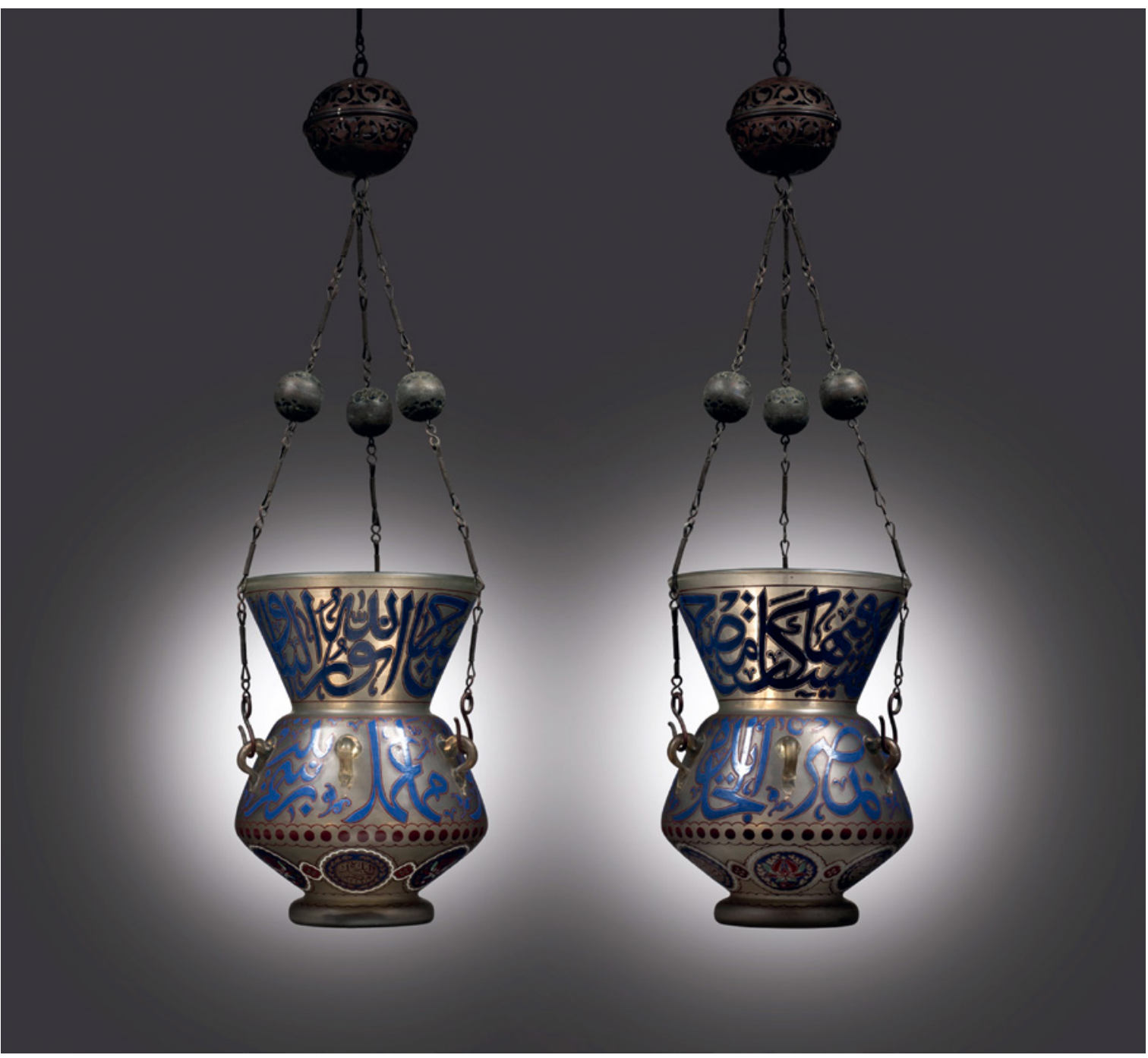

FIGURE 182 A pair of enamelled glass mosque lamps made for the house of Boghos Nubar, dated 1329 AH /1911 AD AUCTIONED ON 25 OCTOBER 2017, AT SOTHEBY'S LONDON, LOT 231. CURRENT LOCATION UNKNOWN

A marked interest for anything "Belle Époque" has driven the curators of the Gayer-Anderson Museum to display many Arabesque furnishings (probably decanted from the storage rooms of ex-royal palaces), in the rooms of the Ottoman ensemble fully rearranged by the Irish Major in the 1930 s. $^{30}$ As there is no labelling, the nonspecialised visitor is at pains to distinguish the

30 Personal conversation with the curator in charge, 2017, with my gratitude to Dina Bakhoum for helping arrange it. additions by Major Gayer-Anderson from the recent ones made to the collections. One suspects furthermore that the invented tradition imagined by Italian carpenters did not exactly correspond to the folk art and period furniture Gayer-Anderson was inclined to promote in his days. But the fact that such types of Revival furniture are being reintroduced today in an historic landmark is good testimony of the value attached to such pieces. Parvis-type furniture is being reinstated in other historic houses as well, at Bayt al-Sihaymi, for 


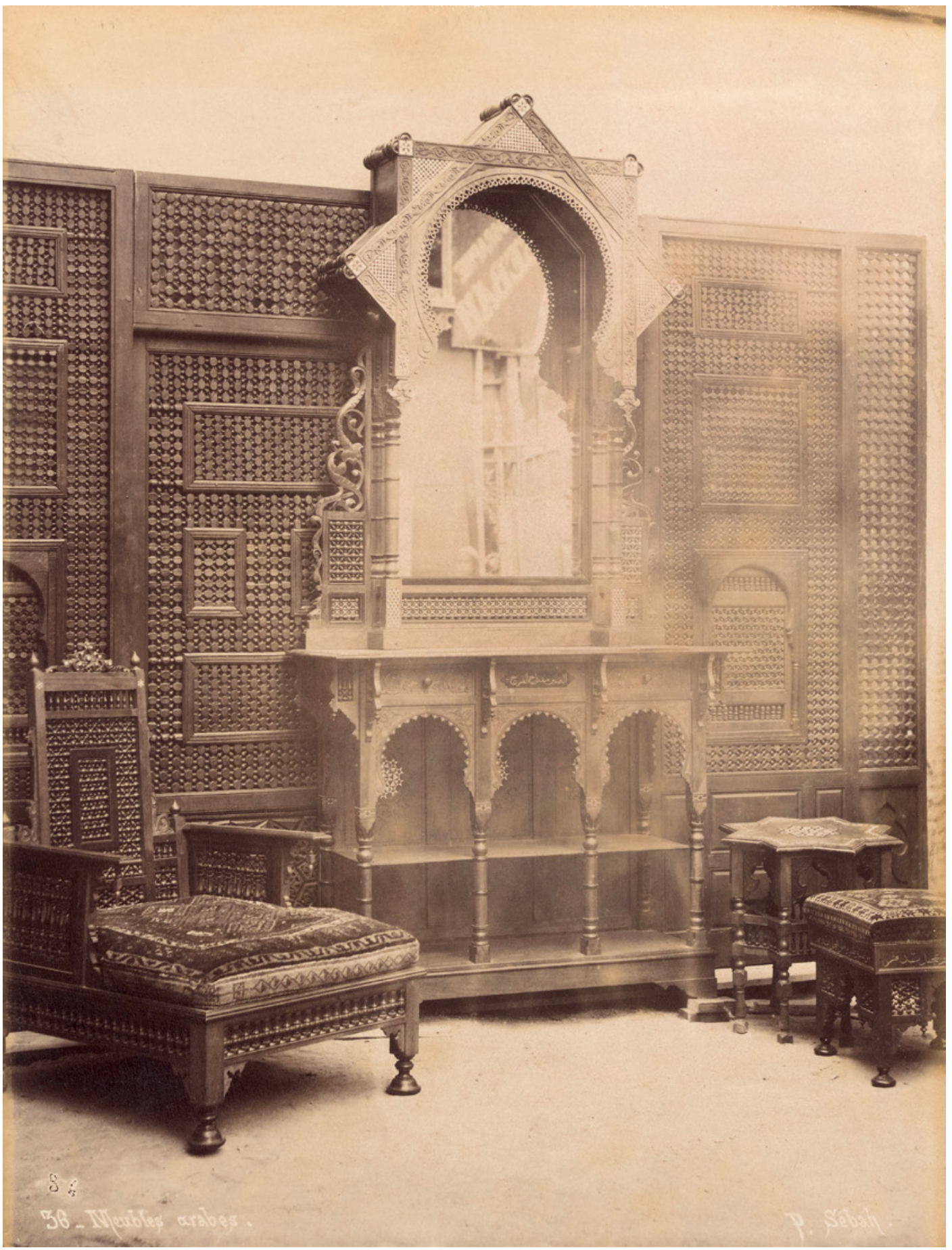

FIGURE 183 Pascal Sebah, Meubles arabes [A set of Arabesque furniture photographed at the studio of the photographer, whose name is reflected in the mirror], before 1886 NEW YORK UNIVERSITY ABU DHABI, AKKASAH: THE CENTER FOR PHOTOGRAPHY, ALBUM ADEN-ÉGYPTE, AD.MC.027, F. 89 


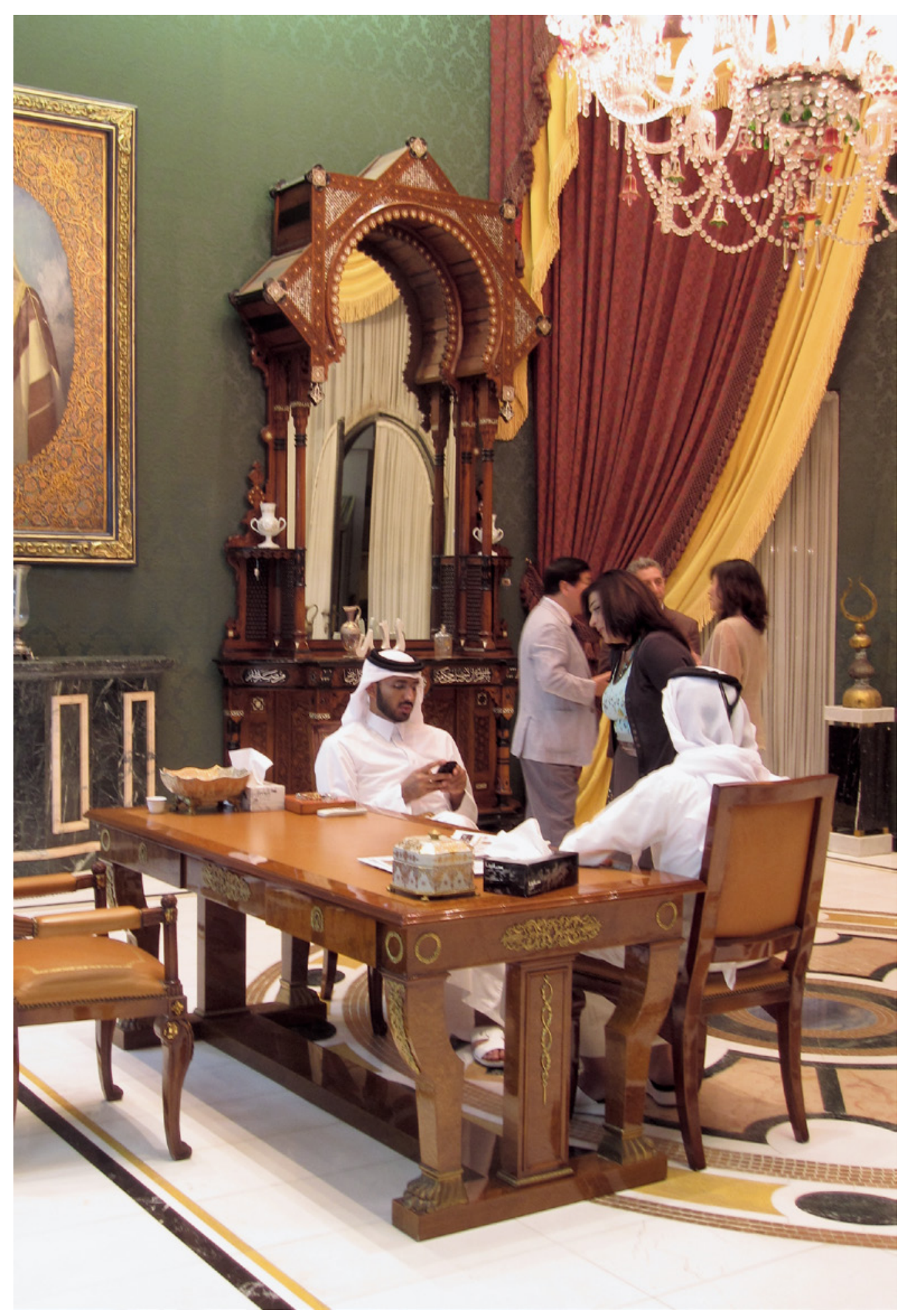

FIGURE 184 Mirrored console attributed to Parvis, in the vestibule of a Qatari residence PHOTOGRAPH BY THE AUTHOR, 2012 
instance. It is a broader trend, and one that deserves to be fully researched.

Even disguise has carved out its own place within Egyptian leisure. Portable photo booths, installed since the 2o1os in front of the Mosque of al-Hakim in Cairo, offer the possibility of being photographed in Mamluk attire or in the guise of a Princess from One Thousand and One Nights for a few Egyptian pounds. It is not exactly cross-cultural dressing as discussed in Chapter 5 , because the clients are not outsiders. Or are they? The props are completely fanciful. They are indeed quite stereotypical, something halfway between Walt Disney imagination and Orientalist kitsch. But the young customers obviously have great fun in the experience. Thanks to a loose continuity with a past that has left many fewer traces in Europe, one is thus offered today (2019), on Egyptian soil, the possibility to share in some of the emotions that went with disguise, and beyond, with a whole range of intercultural engagements. 